\title{
The Three Waves of Italian Reception of Peirce
}

\section{Giovanni Maddalena}

\section{(2) OpenEdition}

\section{Journals}

Electronic version

URL: http://journals.openedition.org/ejpap/484

DOI: 10.4000/ejpap.484

ISSN: 2036-4091

\section{Publisher}

Associazione Pragma

\section{Electronic reference}

Giovanni Maddalena, «The Three Waves of Italian Reception of Peirce», European Journal of Pragmatism and American Philosophy [Online], VI-1 | 2014, Online since 08 July 2014, connection on 17 March 2020. URL : http://journals.openedition.org/ejpap/484 ; DOI : https://doi.org/10.4000/ejpap. 484

This text was automatically generated on 17 March 2020.

\section{(c) $($ ) $९$}

Author retains copyright and grants the European Journal of Pragmatism and American Philosophy right of first publication with the work simultaneously licensed under a Creative Commons AttributionNonCommercial-NoDerivatives 4.0 International License. 


\title{
The Three Waves of Italian Reception of Peirce
}

\author{
Giovanni Maddalena
}

1 Italy was one of the first places outside the US to manifest an interest in pragmatism. However, the reception of Peirce has been discontinuous and asymptotic at the same time. It grew over the time getting closer and closer to a complete acknowledgement of what Peirce had really written, but there were many periods in which studies on Peirce seemed quite stuck or absent. For clarity sake I will divide this reception in three big generational waves.

\section{The First Wave: Leonardo}

2 The first one is the one that coincides with the celebrated adventure of the journal Leonardo. Among the four Italian pragmatists (Papini, Prezzolini, Vailati, Calderoni), Vailati was the most aware of the relevance of Peirce's ideas, even though he had not read that much: for sure he knew the pragmatist maxim and therefore we assume that he read the two papers from the Popular Science Monthly (they were also published in French and this increases possibilities), and he certainly read the article "What pragmatism is?" published on the Monist 1905. Based on the evidence of an envelope, we know that he corresponded once with Peirce but we do not have the content of the letter while we know the letter that Peirce sent to Papini, warning him about different ways of interpreting pragmatism, and the one to Calderoni, with several criticisms of Prezzolini, whose Leonardian pseudonym was Giuliano il Sofista. The distinctions among kinds of pragmatism was the heart of Calderoni's fight on the Leonardo about the different species of pragmatism. From these documents critics have often drawn the conclusion that the Italian pragmatists were split between a "magic" (Prezzolini and Papini) and an "analytic" party (Vailati and Calderoni). As much as this distinction contains elements of truth, this reading is partial and misleading if considered complete. Sure enough, Vailati was Calderoni's mentor and master and he used "we" to indicate the intellectual partnership with him. However, Vailati, who was around forty 
at the epoch of the Leonardo, assumed a role of intellectual teacher for all of them and he was clearly particularly fond of Papini. Papini himself, who was the real engine of the group, well defined the positions of all of them in a short note on the Leonardo, putting himself on the side of a full psychological appreciation of pragmatism through James's formula of the Will to Believe:

There are those (Calderoni) who maintain that many things cannot be grouped together under the same name; that genuine pragmatism is that of Peirce and simply consists of wanting to make the theory more precise [...] and is in full contradiction to the dangerous theories of the Will to Believe, which are more concerned with the good than with the true. Others (Vailati) recognize that, yes, there are two very distinct types of pragmatism - the logical and the psychological - but that despite this fact there are links between the two, points of contact, "elective affinities" that cannot be denied and that justify the single name. (Leonardo IV/5, February 1906, 59-60)

3 To be careful, we should admit at least three pragmatisms among the four Italians (Papini, Prezzolini, Vailati, Calderoni) and it is quite unfair not to consider what they say about themselves. The four of them embraced pragmatism as a reaction against positivism, Kantianism, and idealism. They understood that anti-cartesianism and antiKantianism were the secret root to overcome ancient rationalist dichotomies as doing vs. understanding, practice vs. theory. Somehow they caught the profound unity between Peirce and James about the conception of continuity of experience, a sort of background conception that the correspondence between the two founding fathers of pragmatism confirms. The Italians knew James personally by the visit he made in Rome in 1905, and they knew his thought better than Peirce's. But they did not despise Peirce's thought at all.

We can say that they underlined different tones of the pragmatist unity of experience, but the starting point was absolutely the same and they found a perfect unity around it. Papini gave to the pragmatic formula an existential tone that pushed him to explore even occultism. Prezzolini followed the genial friend, while Vailati and Calderoni stuck to the cognitive theory of Brentano and to a more refined voluntarism until their premature disappearance (Vailati died in 1909 at the age of 46, Calderoni in 1914 at the age of 35). But the four thinkers were not so far from one another. The existentialist attitude was somehow in all of them, even though it relied outside pragmatism. The famous corridor metaphor invented by Papini - for which pragmatism is a method that crosses all philosophical attitudes like the corridor of a hotel crosses different rooms in which people can attend to different disciplines, from science to religion - is a metaphor that first holds for themselves. Finally, it is not true that Papini did not catch the depth of the pragmatic maxim. When in 1923 he wrote the introduction to Vailati's writing, Papini showed to handle Peirce's conditional future implied in the maxim.

Certainly, Vailati's cultivated sense of historicity of science, of hypothetical implications of deductions, and of the relationship of consequentiality between thought and reality were destined to encounter Peirce's views, even though he never caught the possibility of a new paradigm as the abductive one because of the lack of semiotic awareness and of openness to metaphysical realism. Therefore, when the experience of Leonardo was over (1907), the early death of the two major admirers closed the experience of this early reception of Peirce and pragmatism.

6 For years Peirce was present only in sporadic quotations, since pragmatism was severely judged as anti-intellectualism by the dominant idealists. One of those who 
recognized the existence of Peirce was Gramsci, who showed in that way to be open to new forms of thought. Where did Gramsci take any acquaintance with the existence of Peirce? Interestingly, in the same years Mussolini quoted James as one of his masters. Both of them knew a little about pragmatism and pragmatists but the experience of the Leonardo and the epoch of the Journals had a profound impact on Italian culture so that names and main ideas somehow survived. The only real exception of those years was the work of Mario Manlio Rossi, Calderoni's student, who kept recalling the positive impulse of pragmatism of the Peircean stripe in a couple of volumes (Il pragmatismo italiano, 1924; Saggio sul rimorso, 1933) and in one review of the Collected Papers in 1936.

\section{The Second Wave. Masters and Sons}

7 The second wave happened after the Second World War. Turin and Milan were the center and spring of this wave. The two leading figures of that time at the University of Turin were Nicola Abbagnano and Augusto Guzzo, an original critical existentialist the former, an original idealist the latter. A third figure, Luigi Pareyson, younger than the two masters, early emerged directing existentialism toward hermeneutic passing through aesthetics.

8 Abbagnano published the translation of the collection Chance, Love, and Logic (Caso, Amore, Logica, 1956) with the introduction M. R. Cohen. Guzzo did not mention Peirce but encouraged three of his students to study the American thought. Giuseppe Riconda took James, Amalia De Maria Dewey, and Nynfa Bosco Peirce.

9 To Nynfa Bosco we owe both the very first monograph on Peirce in Italian (La filosofia pragmatica di Ch. S. Peirce, 1959) and a new translation of the metaphysical series of the Monist (Dalla scienza alla metafisica, 1977). The latter was accompanied by a second monograph by the same title. Bosco's main idea was that Peirce was a Platonist of an odd stripe who somehow saw the possible convergence of science and metaphysics in a sophisticated hermeneutic. Bosco was anticipating the international scholarship in identifying a hidden profound unity of Peirce's researches in several different fields and the relevance of metaphysics in Peirce's discourse.

10 From Turin Umberto Eco moved his first steps too, following Pareyson's interests for aesthetics. Eco soon transformed his esthetical interests (in which Dewey was already present) in a profound study of semiotics of which the leading figure was Peirce, whose work Eco studied during the 1960s. Eco's interpretation emphasizes Peirce's triadic conception of sign and the dynamic movement of semiosis. In his early works, Eco underlines the function of infinite or unbounded semiosis, while he does not seem to recognize the doctrines of dynamic object, metaphysical realism, logical modalities, cosmological evolutionism. Peirce's semiotics is understood within a nominalistic framework. As Bonfantini says, in this paradigm the dynamic object becomes a cultural object and opens up a way to combine Peircean and Saussurean semiotics. Eco undertakes also a brilliant study on the detective powers of abduction: the book The Sign of the Three. Holmes, Dupin, Peirce, written with Sebeok became a classic.

11 In the meanwhile Eco started to work in Bologna where he developed his own semiotics and his school. Massimo A. Bonfantini and G. Proni are among the main cooperators of Umberto Eco in spreading the knowledge of Peirce through introductory textbooks (Proni, Introduzione a Peirce, 1990), scholarly work (M. A. Bonfantini, La semiosi e l'abduzione, 1986) and translations. They translated many parts of Peirce's semiotics 
following the thematic criterion of the Collected Papers. In 2003 Bonfantini published a collected work of his translations by the title Opere.

The other part of the story of this second wave happened in Milan, where studies on the history of Italian pragmatism were undertook by Dal Pra and Preti since the 1950s. In the 1970s Ludovico Geymonat, a radical marxist scholar who had quoted Peirce also in 1930s while he was participating to the Circle of Vienna, inserted Peirce in his History of Logic (Storia del pensiero filosofico e scientifico), somehow putting him within a neopositivist framework.

In the same years, from a different perspective, Carlo Sini published his history of pragmatism and started his original way of understanding Peirce (Il pragmatismo americano, 1972). Sini gave a comprehensive overview of Peirce's work, stressing the original path of Peirce's relational understanding of categories and the peculiar kind of hermeneutics that can stem from Peirce's semiotic. Very interestingly, Sini stressed also the nihilist hint of Peirce's cosmological conception and the close tie between this origin from nihil and the fate of Western metaphysics from the invention of the alphabet to technology (Figure dell'enciclopedia filosofica, 2004-6). This path shows how Peirce's philosophy can join forces with Heidegger's hermeneutics. Comparing James and Peirce, Sini clearly underlined their differences and Peirce's logical capacity. Last but not least, Sini saw the great importance of Existential Graphs and their iconic capacity to represent logical thought.

Among the few other significant contributes of this epoch, it is important to recall the two essays by A.Guccione Monroy (Peirce e il pragmatismo americano, 1959) and A. Salanitro (Peirce e il problema dellinterpretazione, 1969, completely dedicated to semiotics), and the figure of F. Rossi Landi, Morris scholar, who gave impulse to studies that had to deal with Peirce's semiotics. This semiotic stripe was then carried on by his student A. Ponzio.

The event that better represents, and somehow closes, this second wave is the congress "Peirce in Italia," held in 1990 in Napoli (Peirce in Italia, 1993). The papers of all the main characters of this second wave are collected in the proceedings, and two significant articles by M. Quaranta and A. Martone recall the reception of Peirce.

\section{The Third Wave. A Contemporary Living Pragmatism}

The third wave regards the ongoing studies on Peirce. It has two central places: Rome and Milan. From the late eighties Rossella Fabbrichesi, Sini's student, and Rosa M. Calcaterra started their studies with several monographic books and translations. Fabbrichesi deepened Sini's insights on semiotics and categorical relationships (Sulle tracce del segno, 1986; Il concetto di relazione in Peirce, 1992), compared Peirce' semiotic and phenomenology with Leibniz, Goethe, Wittgenstein (Continuità e variazone, 2001; Peirce e Wittgenstein: un incontro, 2014), Heidegger, and Nietzsche, and she finally reached a vision that blends Peirce's view with hermeneutics and a philosophical social interpretation of biological evolutionism (Pragmatismo ed ermeneutica, 2009). In her last work she proposes an interpretation of the social body which stems from Peirce's category of thirdness and from Royce's conception of community (In comune. Dal corpo proprio al corpo comunitario, 2012). Fabbrichesi is also translator of a collection of Peirce's writings on categories (Categorie, 1992), founder and leader of the Centro Studi 
Peirce at the University of Milan, the only place in Italy where you can find all Peirce's manuscripts.

17 Calcaterra, who had heard about Peirce from her professor Filiasi Carcano, came to Peirce through studies on Habermas. The normative and social understanding of cognitive semiotic of the 1860 s and the 1870 s was the focus of her early book Interpretare l'esperienza. Scienza Metafisica Etica nella filosofia di C. S. Peirce (1989), while she later focused on the same intertwining between normative sciences and logic in Peirce's later works. Later on she broadened the spectrum of her interests to all pragmatists critically reconstructing the relationship between pragmatism and analytic philosophy (as editor of New Perspectives on Pragmatism and Analytic Philosophy) and giving an original reading of classic pragmatism as common project based on a qualified conception of experience (Pragmatismo: $i$ valori dell'esperienza, 2003; Idee concrete. Percorsi nella filosofia di Dewey, 2011). This reading is the distinctive characteristic of the Rome school of pragmatism and the continuity of the pragmatist project from Peirce to contemporary neo-pragmatists is the content of La filosofia in pratica (in print).

18 Embarrassingly enough, the third character of this third wave is my work. Coming from Turin and having studied with Nynfa Bosco, I started working on Peirce in Rome. After a dissertation on Peirce's very late manuscripts (Istinto razionale, 2003) I focused my research on the boundaries between logic and metaphysics proposing a reading of several Peircean unfinished topics according to a metaphysical realism that relies upon the mathematical conception of continuity (Metafisica per assurdo, 2009). This conception accounts also for a profound synthetic drive in Peirce that could never be completed and explains why Peirce was abandoning and contrasting Kant's legacy over the years. After a close study of the semiotic characteristics of Existential Graphs, I proposed a different pattern for synthetic/analytic/vague reasoning and a synthetic tool for understanding syntheticity: complete gesture, an action that carries on a meaning thanks to its semiotic and phenomenological characteristics (Philosophy of gesture, 2014). I also provided a huge $(700 \mathrm{p}$.) chronological translation of some of Peirce's works (Scritti scelti, 2005) and, with Marco Annoni, a translation of a selection of letters between Peirce and James (Alle origini del pragmatismo, 2011).

The three of us, with Carlo Sini and Susanna Marietti, launched an association called Pragma that unites the efforts of the schools of Rome and Milan, and the Centro Studi Peirce. The Associazione Pragma reunites many good scholars who gave important specialized interpretations of pragmatism and Peirce. Among others I want to recall Susanna Marietti, author of an important book on Existential Graphs and one of the founder of Pragma (Icona e diagramma, 2001). She also translated some important writings on Existential Graphs (Pragmatismo e Grafi Esistenziali, 2003). Besides Marietti, important authors are Giovanni Tuzet, who gave a brilliant reading of abduction in Philosophy of Law (La prima inferenza. L'abduzione di C.S. Peirce, 2006) and Maria Luisi, who worked on the comparison between Peirce's and Husserl's phenomenologies and a translation of Peirce's writings on phenomenology (Esperienza e percezione, 2009). Very good studies are also emerging from Claudio Paolucci, Marco Stango, Gabriele Gava, Francesco Bellucci, Marco Annoni, and Emanuele Fadda who are working on Peirce's iconism, the conception of morality, purposefulness, logic, bio-semiotics, and the relationship with Saussure respectively. 
20 Associazione Pragma is also the owner of the European Journal of Pragmatism and American Philosophy founded and directed by Rosa Calcaterra, Roberto Frega, and me.

\section{BIBLIOGRAPHY}

BONFANTINI M. A. \& A. MARTONE (eds), (1993), Peirce in Italia, Napoli, Liguori.

MADDALENA G. \& G. TUZET (2007), I pragmatisti italiani. Tra alleati e nemici, Milano, Alboversorio.

\section{AUTHOR}

GIOVANNI MADDALENA

Università del Molise, Italy

maddalena[at]unimol.it 